\title{
Somut ve Somut Olmayan Kültürel Miras Değerleriyle Çankırı Kenti ve Turizme Katkısı
}

\author{
Betül Tülek ${ }^{1 *}$ \\ 1* Çankırı Karatekin Üniversitesi, Orman Fakültesi, Peyzaj Mimarlığı Bölümü, Çankırı, Türkiye, (ORCID: 0000-0002-6584-041X), betultulek@karatekin.edu.tr
}

(İlk Geliş Tarihi 2 Şubat 2021 ve Kabul Tarihi 28 Nisan 2021)

(DOI: $10.31590 /$ ejosat.889708)

ATIF/REFERENCE: Tülek, B. (2021). Somut ve Somut Olmayan Kültürel Miras Değerleriyle Çankırı Kenti ve Turizme Katkısı. European Journal of Science and Technology, (23), 827-836.

$\ddot{O} \mathbf{z}$

Kültürel miraslar nesiller boyunca uzanan toplumların kültür, değer ve gelenekleridir. Kültürel mirasın korunması ve bu mirasın gelecek nesillere aktarılması, geçmişten günümüze gelen ulusal ve uluslararası anlaşmalar, yasalar ve yönetmeliklerle dünya politikası haline gelmiştir. Kentler toplumların kültürel, sosyal ve ekonomik yapısının mekândaki ifadesi olarak tanımlanmakta ve kimliğini tarihi gelişiminden almaktadır. Özellikle birbirine benzeyen yapıların çoğunlukta olduğu bugünün kentlerinde, kentlere kimlik kazandıran ve kentlilerin kendilerini kentle özdeşleştirebileceği en önemli öğeler kültürel miraslarıdır. Kültürel mirasların korunması, yönetilmesi ve sürdürülebilirliğinin sağlanmasında en etkin yollardan birisi turizmdir. Turizmin etkileri içinde yerel halkın yaşam seviyesinin yükseltilmesi, yeni iş olanaklarının yaratılması gibi ekonomik ve sosyo-kültürel gelişmeler de yer almaktadır.

Çankırı Kenti tarihsel gelişim süreçleri Prehistorik dönem, Antik dönem, Hititler dönemi, Karanlık dönem, Makedonyalılar dönemi, Paflagonyalılar dönemi, Galatalar dönemi, Roma dönemi, Bizans dönemi, Selçuklu dönemi, Kurtuluş Savaşı dönemlerinden oluşmaktadır. Bu dönemlere ait çok sayıda somut ve somut olmayan kültürel miras değeri bulunmaktadır. Bu araştırma kapsamda Çankırı kent merkezi ve yakın çevresinde bulunan ve somut kültürel miraslar kapsamına giren Taş Mescit, Çankırı Kalesi ve Emir Karatekin Bey Türbesi, Büyük Cami, Saat Kulesi, Buğday Pazarı Medresesi, Çivitçioğlu Medresesi, Çankırı Tarihi Çamaşırhanesi, İnandık Vazosu, Taş Mektep, İstiklal Yolu, Çankırı tuz mağarası ile somut olmayan kültürel miraslar kapsamına giren Yaran Kültürü, Takım Yemeğinden oluşan Çankıı’’nın geleneksel kültürünün en tipik örnekleri değerlendirilmiştir. Araştırmada, kültürel miras ile turizm ilişkisi üzerine odaklanılmış ve kültürel miras değerlerinin Çankırı kent turizmine olan katkıları incelenmiştir.

Anahtar Kelimeler: Kültür, Kültürel Miras, Turizm, Kent Turizmi, Çankırı.

\section{Çankırı City with Tangible and Intangible Cultural Heritage Values and Their Contribution to Tourism}

\begin{abstract}
Cultural heritage is the culture, value and traditions of the societies that go through for generations. Preservation and transfer to future generations of this heritage has become a world policy with national and international agreements, laws and regulations from past to present. Cities are defined as the spatial expression of the cultural, social and economic structure of societies and take their identity from historical development. Especially in today's cities, where the most of the buildings resemble each other, the most important elements are their cultural heritage that give identity to cities and which the citizens can identify themselves with the city. One of the most effective ways to protect, manage and sustain cultural heritage is tourism. Tourism effects include economic and socio-cultural developments such as raising the life quality level of the local population and creating new business opportunity.

Historical development processes of Çankırı city consist of Period of Prehistoric, Period of Ancient, Period of Hittites, Period of Dark, Period of Macedonians, Period of Paflagonians, Period of Galatians, Period of Roman, Period of Byzantine, Period of Seljuk, Period of Independence War. There are a great number of tangible and intangible cultural heritage values belonging to these periods. Within this study, Stone Masjid, Çankırı Castle and Emir Karatekin Bey Tomb, Grand Mosque, Clock Tower, Buğday Pazarı Madrasah, Çivitçioğlu Madrasah, Çankırı Historical Laundry, İnandık Vase, Stone School, İstiklal Way, Çankırı Salt Cave were evaluated as tangible cultural heritage and Çankırı Yaran Culture, Team Dinner were evaluated as intangible cultural heritage; which are the most typical examples of the Çankırı traditional culture in Çankırı city center and its vicinity. The study focused on the relationship between cultural heritage and tourism and the contribution of cultural heritage values to Çankırı city tourism was examined.
\end{abstract}

Keywords: Culture, Cultural Heritage, Tourism, Urban Tourism, Çankırı.

\footnotetext{
* Sorumlu Yazar: Çankırı Karatekin Üniversitesi Orman Fakültesi Peyzaj Mimarlığı Bölümü, Çankırı, Türkiye, ORCID: 0000-0002-6584-041X, betultulek@karatekin.edu.tr
} 


\section{Giriş}

İnsanın kültürel, sosyal ve ekonomik yapısının mekândaki ifadesi olarak tanımlanan kent, kimliğini tanımlayan özelliklerini tarihi gelişiminden almaktadır. Özellikle birbirine benzeyen yapıların çoğunlukta olduğu bugünün kentlerinde, kentlere kimlik kazandıran ve kentlilerin kendilerini kentle özdeşleştirebileceği en önemli öğelerden biri kültürel, sosyal, ekonomik, arkeolojik ve estetik değerlere sahip olan kültürel miraslarıdır. Kültür turizmi ise kentlerin kimliklerini oluşturan doğal ve tarihsel kültür varlıklarını, kültürel etkinlikleri ve güncel sanat eserlerini, kültür sanayilerinin sonuçlarını, bazı sosyo-ekonomik olguları turistik bir ürün biçiminde hizmete sunan bir turizm anlayışıdır. Bu bağlamda araştırma alanı olan Çankırı kenti ve yakın çevresindeki somut ve somut olmayan kültürel mirasları, kent kimliğini oluşturan ve bu açıdan kent tanıtımına katkı sağlayan ve kültür turizmi imkanı kazandıran unsurlar olmaları sebebiyle Çankırı kenti için önemli birer unsurdur. Bu araştırma kapsamında İç Anadolu Bölgesinde bulunan Çankırı kenti, tarihsel gelişim süreçleri içerisinde, bu süreçlerle ilişkili çok sayıda somut ve somut olmayan kültürel miras özellikleri ile incelenmiş, bu özelliklerinin kent ve kültür turizmine olan katkıları tartışılmıştır.

\section{Materyal ve Metot}

\subsection{Materyal}

Araştırmanın ana materyalini Çankırı kenti oluşturmaktadır. Çankırı kentinin büyük bir bölümü İç Anadolu Bölgesinde, bazı bölümleri de Karadeniz Bölgesinde yer almakta olup, İç Anadolu ile Batı Karadeniz Bölgesi geçiş alanındadır. İl batıda Bolu, kuzeybatıda Karabük, kuzeyde Kastamonu, doğuda Çorum ve güneyde Ankara ve Kırıkkale ile sınırlandırılmıştır. İlin kuzey sınırındaki dağlar, aynı zamanda en yüksek kesimini oluşturmaktadır (Çankırı Ticaret ve Sanayi Odası, 2019).

Çankırı ili nüfusu 2020 yılsonu itibariyle 192.428 olarak belirlenmiş, bu nüfusun $\% 73,8^{\prime}$ i şehirlerde yaşadığ belirtilmiştir. İlin yüzölçümü $7.542 \mathrm{~km}^{2}$ 'dir. İlde $\mathrm{km}^{2}$ başına 26 kişi düşmektedir. Nüfus artış oranı en yüksek ve en düşük ilçeler ise

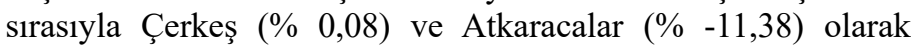
belirtilmektedir. Çankırı'da TÜİK verilerine göre merkez ilçeyle beraber 12 İlçe, 15 belediye, bu belediyelerde 96 mahalle ve ayrıca 371 köy vardır (TÜIK, 2021). Çankırı merkez ilçe, köy ve kasabalarında Türk Milli Kültürü yaşatılmaktadır ve genel olarak kapalı toplum özelliği görülmektedir. Çankırı köyleri bugün hala köy odalarına sahiptir ve misafirperverlikler yaşatılmaktadır. Düğün, bayram gibi özel günlerde de halkın birbirine, gelenek ve göreneklere bağlılıkları gözlenebilmektedir (Çankırı Belediyesi, 2019a) (Şekil 1).

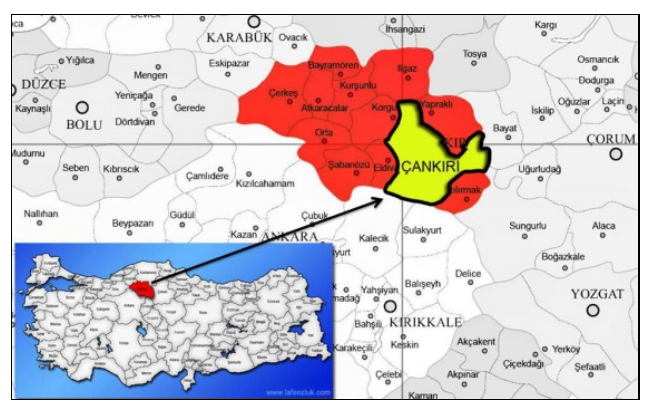

Şekil 1.Araştırma alanı konumu
Kültürel mirasların kent turizmindeki yeri ve önemi açısından potansiyel taşıyan alanlarda öncelikle kültür envanteri çıkartmak, etüt yapmak, turizm için gerekli şartların tespit edilmesi bakımından önemlidir. Araştırmanın temel amacı; Çankırı kent merkezi ve yakın çevresinde yer alan önemli kültür varlıklarının tespiti, analizi ve turizm potansiyellerinin belirlenmesidir.

Bu araştırmada, Çankırı kentindeki kültürel miras ve kültür turizmi ilişkisi ortaya konmuş ve kültürel miraslara ilişkin elde edilen veriler ile Çankırı kenti somut ve somut olmayan kültürel miras değerlerinin kent turizmine deneyimsel, sosyal ve ekonomik katkıları Teo ve Yeoh (1997), Bachlaitner ve Zins (1999), MacDonald ve Joliffe (2003), Bahçe (2009), Altuntaş ve Tülek (2012) çalışmaları dikkate alınarak incelenmiştir. Araştırma yönteminin birinci aşamasında, alana ilişkin kültür envanteri çıkarılmış, turizm ve kültür kavramları ve Çankırı kentine ait sözlü, yazılı, görsel ve sayısal materyaller toplanmıştır. Íkinci aşamada veriler analiz edilerek Çankırı kent merkezi ve yakın çevresindeki doğal, beşeri ve ekonomik özellikleri ile ilçenin somut ve somut olmayan kültürel mirasları tek tek ele alınmıştır. Araştırmanın son aşamasında ise ilçenin kültür turizmi potansiyelini oluşturan miras alanlarının turizmine olan katkıları incelenerek, sorunlar ve çözüm önerilerine yer verilmiştir. Araştırma, Çankırı Belediyesi, Çankırı Valiliği, Çankırı İl Kültür ve Turizm Müdürlüğü verileri ile de desteklenmiştir. Araştırma sonucunda, kentin kültür turizmi ile kalkınması ve sahip olunan zengin kültürel mirasın korunması, yaşatılması, kültür varlıklarının hak ettikleri değeri kazanması ve bilime katkı sağlanması beklenmektedir.

\section{Araștırma Sonuçları ve Tartışma}

\subsection{Kültür ve Kültürel Miras Kavramı}

Kültür sözcüğü 'Cultura' veya 'Colere' sözcüklerinden türetilmiştir. Latince karşılığı olarak, 'bakmak' 'yetiştirmek' olarak belirtilmektedir (Meydan Uygur ve Baykan, 2006). Pek çok turist farklı toplumlarla ilgili bilgi sahibi olmak için seyahatlerde bulunmaktadır. Burada kültür kavramının da etkinliği büyüktür. Turistler farklı ulusların kültürlerini tanımak için seyahat etmekte ve konaklamakta olup, bu turizm şekli kültür turizmi olarak adlandırılmaktadır (Arınç, 2002).

Kültürel miras kavramı bir miras değeri olarak geçmişten gelen ve geleceğe aktarılmak istenen, sosyal, kültürel, estetik açıdan toplumların sahip olduğu tüm unsur ve eserlerin bütününü tariflemektedir (Can, 2009). Kültürel miras insanoğlunun binlerce yıllık yaşam deneyiminin, aklının ve yaratıcılığının günümüze ulaşmış somut ve somut olmayan değerleridir. 17 Ekim 2003 tarihinde UNESCO tarafindan kabul edilen ve Türkiye'nin de 27 Mart 2006 tarihinde taraf olduğu Somut Olmayan Kültürel Mirasın Korunması Sözleşmesi mirasların korunması kapsamında önemli amaçlara sahiptir. Bu amaçlardan biri somut olmayan kültürel mirasların önemi konusunda yerel, ulusal ve uluslararası düzeyde duyarlılığı ve farkındalığı artırmaktır. Küreselleşen dünyanın getirdiği "tek tip"leştirici etkilerle yok edilmekte olan kültürel çeşitliliği ve kültürel mirası korumaya, çalışan Somut Olmayan Kültürel Miras (SOKÜM) Sözleşmesi'nin "Somut Olmayan Kültür" kavramı tanımlayan yaklaşımı, koruma, yaşatma ve geliştirme amacı altında önemli olanaklar sağlamaktadır (Yıldırım Saçılık ve Toptaş, 2017).

\subsubsection{Somut kültürel miras}


Türkiye'nin somut kültürel mirasları Kültür ve Turizm Bakanlı̆̆ı'na göre kazılar ve araştırmalar, müzecilik faaliyeti, dünya miras alanları ve antik kentler, sanal müzeler ve diğer mekanlar olarak farklı kategorilere ayrılmaktadır (T.C. Kültür ve Turizm Bakanlığı, 2019). Türkiye kültür ve tabiat varlıkları açısından son derece önemlidir ve zengin bir kültürel potansiyele sahiptir. Kültür Varlıkları ve Müzeler Genel Müdürlüğü’nün sorumluluğu altında yürüttüğü çalışmalar neticesinde bugüne kadar UNESCO Dünya Miras Listesi'ne 18 adet varlığın alınmasını sağlanmıştır (UNESCO, 2021a) (Tablo 1).

Tablo 1. UNESCO Dünya Mirasları Listesi (UNESCO, 2021a)

\begin{tabular}{rll}
\hline Yll & Miras İsimleri & Yeri \\
\hline 1985 & Divriği Ulu Camii ve Darüşşifası & Sivas \\
\hline 1985 & İstanbul'un Tarihi Alanları & İstanbul \\
1985 & $\begin{array}{l}\text { Göreme Millî Parkı ve } \\
\text { Kapadokya(Karma Miras Alanı) }\end{array}$ & Göreme \\
\hline 1986 & Hattuşa: Hitit Başkenti & Çorum - Sungurlu \\
\hline 1987 & Nemrut Dağı & Adıyaman -Kahta \\
\hline 1988 & $\begin{array}{l}\text { Hieropolis-Pamukkale } \\
\text { Miras Alanı) }\end{array}$ & Denizli \\
\hline 1988 & Xanthos-Letoon & Antalya - Muğla \\
\hline 1994 & Safranbolu Şehri & Karabük \\
\hline 1998 & Truva Arkeolojik Alanı & Çanakkale \\
\hline 2011 & $\begin{array}{l}\text { Edirne Selimiye Camii ve } \\
\text { Külliyesi }\end{array}$ & Edirne \\
\hline 2012 & Çatalhöyük Neolitik Alanı & Konya \\
\hline 2014 & $\begin{array}{l}\text { Bursa ve Cumalıızık: Osmanlı } \\
\text { İmparatorluğunun Doğuşu }\end{array}$ & Bursa \\
\hline 2014 & $\begin{array}{l}\text { Bergama Çok Katmanlı Kültürel } \\
\text { Peyzaj Alanı }\end{array}$ & İzmir \\
\hline 2015 & $\begin{array}{l}\text { Diyarbakır Kalesi ve Hevsel } \\
\text { Bahçeleri Kültürel Peyzajı }\end{array}$ & Diyarbakır \\
\hline 2015 & Efes & İzmir \\
\hline 2016 & Ani Arkeolojik Alanı & Kars \\
\hline 2017 & Aphrodisias & Aydın \\
\hline & Göbekli Tepe & Şanlıurfa \\
\hline
\end{tabular}

\subsubsection{Somut olmayan kültürel miras}

Somut Olmayan Kültürel Miras kavramı UNESCO (2003) tarafindan; toplulukların, grupların ve kimi durumlarda bireylerin, kültürel miraslarının bir parçası olarak tanımladıkları uygulamalar, temsiller, anlatımlar, bilgiler, beceriler ve bunlara ilişkin araçlar, gereçler ve kültürel mekânlar biçiminde açıklanır. Gelecek nesillere aktarılan bu miras, toplulukların ve grupların çevreleriyle, doğayla ve tarihleriyle etkileşimlerine bağlı olarak, sürekli biçimde yeniden yaratılmakta ve bu onlara kimlik ve devamlılık duygusu vermekte; böylelikle kültürel çeşitliliğe ve insan yaratıcılığına duyulan saygıyı arttırmaktadır (T.C. Kültür ve Turizm Bakanlığı, 2019).

Gelecek nesillerin kültürel çeşitliliği görmesi ve paylaşması oldukça önemlidir ve önlemler alınması gerekmektedir. UNESCO tarafindan bu amaçla 1999 yılında düzenlenen konferansta somut olmayan kültürel miraslar için bir program oluşturulmasına karar verilmiştir. Somut olmayan kültürel mirasın korunması UNESCO Genel Kurulununda 17/10/2003 tarihinde sözleşmeye bağlanmıştır. Somut Olmayan Kültürel Miraslar 5 kategoride toplanmaktadır (Can, 2009):

- Sözlü gelenek ve anlatımlar, dil

- Gösteri sanatları
- Toplumsal uygulamalar, ritüeller, şölenler, festivaller

- Doğa ve evrenle ilgili bilgi ve uygulamalar

- El sanatlarıdır.

Somut Olmayan Kültürel Mirasın Korunması Sözleşmesinin birinci amacı somut olmayan kültürel mirası korumaktır ve koruma "yaşayabilirliğini garanti altına almak" anlamına gelmektedir. Sözleşmenin diğer amaçları ise şöyle sıralanabilir (Anonim, 2011); İlgili toplulukların, grupların ve bireylerin somut olmayan kültürel mirasına saygı göstermek, Somut olmayan kültürel mirasın önemi konusunda yerel, ulusal ve uluslararası düzeyde duyarlılığı arttırmak ve karşılıklı değerbilirliği sağlamak, Uluslararası işbirliği ve yardımlaşmayı sağlamak. Türkiye 27 Mart 2006 tarihinde sözleşmeye resmen taraf olmuştur. Türkiye'nin ilk yazımları Hükümetler arası Komite'nin 2008 yılında İstanbul'da gerçekleşen Üçüncü Olağan Toplantısı'nda daha önce ilan edilen Başyapıtların 16. Madde kapsamındaki Somut Olmayan Kültürel Miras Temsili Listesine alınmasıyla gerçekleşmiş ve 2020 yılı itibariyle bu listedeki miras sayısı 20 olmuştur (UNESCO, 2021b) (Tablo 2).

Tablo 2.UNESCO İnsanlı̆̆ın Somut Olmayan Kültürel Mirası Temsili Listesi (UNESCO, 2021b)

\begin{tabular}{|c|c|}
\hline Yll & Somut Olmayan Kültürel Miraslar \\
\hline 2008 & Meddahlık \\
\hline 2008 & Mevlevi Sema Töreni \\
\hline 2009 & Aşılık Geleneği \\
\hline 2009 & Nevruz (Çokuluslu) \\
\hline 2009 & Karagöz \\
\hline 2010 & Geleneksel Sohbet Toplantıları \\
\hline 2010 & Kırkpınar Yağlı Güreş Festivali \\
\hline 2010 & Alevi - Bektaşi Ritüeli Semah \\
\hline 2011 & Tören Keşkeği Geleneği \\
\hline 2012 & Mesir Macunu Festivali \\
\hline 2013 & Türk Kahvesi Kültürü ve Geleneği \\
\hline 2014 & Ebru : Türk Kağıt Süsleme Sanatı \\
\hline 2016 & Geleneksel Çini Ustalığ \\
\hline 2016 & $\begin{array}{l}\text { İnce Ekmek Yapma ve Paylaşma Kültürü: Lavaş, } \\
\text { Katırma, Jupka, Yufka (Çokuluslu) }\end{array}$ \\
\hline 2017 & Bahar Kutlaması: Hıdrellez (Çokuluslu) \\
\hline 2017 & $\begin{array}{l}\text { Islık Dili (UNESCO Acil Koruma Gerektiren } \\
\text { Somut Olmayan Kültürel Miras Listesi) }\end{array}$ \\
\hline 2018 & $\begin{array}{l}\text { Dede Qorqud/Korkyt Ata/Dede Korkut Mirası: } \\
\text { Destan Kültürü, Halk Masalları ve Müzik } \\
\text { (Çokuluslu) }\end{array}$ \\
\hline 2019 & Geleneksel Türk Okçuluğu \\
\hline 2020 & $\begin{array}{l}\text { Minyatür Sanatı (Azerbaycan, İran ve Özbekistan } \\
\text { ile Ortak Dosya) }\end{array}$ \\
\hline 2020 & $\begin{array}{l}\text { Geleneksel zekâ ve strateji oyunu: } \\
\text { Togyzqumalaq, Toguz Korgool, Mangala / } \\
\text { Göçürme (Kazakistan ve Kırgızistan ile Ortak } \\
\text { Dosya) }\end{array}$ \\
\hline
\end{tabular}

\subsection{Turizm ve Kültür Turizmi Kavramı}

Turizm kavramı, dinlenme, eğlenme, görme, tanıma vb. amaçlar ile yapılan gezi; bir ülkeye veya bir bölgeye turist çekmek için alınan ekonomik, kültürel, teknik önlemlerin, yapılan çalışmaların tümü olarak tanımlanmaktadır (TDK, 2019). Birleşmiş Milletler Dünya Turizm Örgütü (UNWTO) tarafından turizm, insanların yaşadıkları yerler dışında iş, sağlık, spor, tatil, eğlenme, kültür veya aile ziyaretleri, kongreler ve seminerlere katılmak gibi sebeplerle, tek başına veya grup olarak 
yaptıkları seyahatler ve gidilen yerde 24 saatten fazla veya bir ülkenin herhangi bir konaklama tesisinde en az 1 gece konaklamalarından ortaya çıkan hareketler olarak tanımlanmaktadır (Bıçkı ve ark., 2013).

Kültür turizmini, "bir bölgede yaşayan bir insan grubuna özgü somut ve somut olmayan özelliklerinin, ziyaretçinin ilgi ve amacına göre gerçek ortamında deneyimlenmesi için yapılan seyahat" olarak tanımlamak mümkündür (Bahçe, 2009).

\subsection{Kültürel Mirasların Turizm Üzerindeki Etkileri}

Dünyadaki kültür mirası ürünlerinin, insanlar tarafından görülmesine yönelik talep artışı ve bunların insanlığın beğenisine sunulmak isteğinin neticesinde kültürel miras zenginliği olan mekânlar, kültür turizminin gelişme yerleri olarak görülmüştür. Söz konusu mekânların, turizme kazandırılması çalışmaları günümüzde giderek yaygınlaşmaktadır. Kültür turizminin geliştirilmesine yönelik çabalar, özellikle kültürel miras bakımından belirli bir potansiyeli barındıran alanlarda yoğunlaşmaktadır. Kültür turizmi, daha çok özgünlüğünü koruyan ve nispeten daha az bozulmuş kültürlerin bulunduğu alanlarda daha iyi bir gelişme trendi yakalamaktadır (Sezer, 2017).

Kültürel varlıkların turizm üzerindeki olumlu etkilerinden en önemlisi, yerel halkın yaşam seviyesini yükseltmesi ve yeni iş olanakları yaratması gibi ekonomik etkileridir. Ekonomik gelişme, sosyo-kültürel gelişmeyi de beraberinde getirmektedir. Yerel halkın toplum bilincinin yükselmesi, korumaya yönelik yatırımların da artmasını sağlamaktadır. Kültür turizm ile elde edilen ekonomik kazanç, kültürel mirasın korunması için gerekli finansal desteği de sağlamaktadır. Çevreyi ve kültürel mirası koruma adına yapılan harcamalar, uzun dönemde ekonomik açıdan olumlu bir gelişmeye sebep olmaktadır. Bu nedenle kültür turizmi ve kültürel miras, sürdürülebilirlik ve ekonomik gelişme açısından birbirlerine gereksinim duyan iki olgudur (Akgül, 2003).

\section{4.Çankırı Kentinde Turizm ve Kültürel Miras Potansiyeli}

Birleşmiş Milletler Dünya Turizm Örgütü (UNWTO) verilerine göre dünya genelinde seyahat eden kişi sayısı 2017 yılında \% 7'lik artışla 1.322 milyon seviyesine ulaşmıştır. $\mathrm{Bu}$ oran 2010 yilından bu yana son 7 yılda elde edilen en yüksek büyüme rakamıdır. Türkiye'ye 2017 yılında gelen ziyaretçi sayısı bir önceki yıla göre \% 28 artarak 32 milyon 410 bin 34'e çıkmış ve turizm geliri de \% 19 artışla 26,3 milyar dolara yükselmiştir. Türkiye'nin pazardan aldığı bu payın arttırılması için 2023 Türkiye Turizm Stratejisi gerekli tedbirler içermektedir. Stratejide 2023 yılında 63 milyon turist, 86 milyar Amerikan Doları dış turizm gelirine ulaşılması hedeflenmektedir (UNWTO, 2019).

T.C. Kuzey Anadolu Kalkınma Ajansı tarafından İstatistiki Bölge Birimleri Sınıflandırılması (İBBS) yapılmıştır. Bu sınıflandırmaya göre Türkiye, birinci düzeyde 12 bölgeye, ikinci düzeyde 26 alt bölgeye ve üçüncü düzeyde ise 81 ile ayrılmıştır. Buna göre TR82 Alt Bölgesi Kastamonu, Çankırı ve Sinop'tan oluşmaktadır. Bu bağlamda TR82 Alt Bölgesi'nin turizm potansiyelinin etkin biçimde kullanılması ayrı bir önem taşımaktadır (Kuzka, 2013). Çankırı için tüm belediye ve işletme belgeli tesislere gelen yerli yabancı turist sayısı 2020 yılı için e-ISSN: 2148-2683
8.996, geceleme sayısı 15.066 olarak tespit edilmiştir. Bu sayı içerisinde yabancı turistin payı oldukça düşüktür (Tablo 3) (Çankırı Belediyesi, 2021a).

Tablo 3. Turizm Işsletmesi Belgeli Tesisler (Çankırı Belediyesi, 2021a).

\begin{tabular}{|c|c|c|c|c|c|}
\hline Yll & $\begin{array}{c}\text { Tesis } \\
\text { Adedi }\end{array}$ & $\begin{array}{c}\text { Yatak } \\
\text { Kapasitesi }\end{array}$ & Müşteri & Giriş & Geceleme \\
\hline \multirow{2}{*}{2009} & \multirow{2}{*}{2} & \multirow{2}{*}{177} & Yerli & 22147 & 26153 \\
\hline & & & Yabancı & 51 & 93 \\
\hline \multirow{2}{*}{2010} & \multirow{2}{*}{2} & \multirow{2}{*}{202} & Yerli & 22814 & 27030 \\
\hline & & & Yabanc1 & 40 & 105 \\
\hline \multirow{2}{*}{2011} & \multirow{2}{*}{2} & \multirow{2}{*}{202} & Yerli & 26718 & 33903 \\
\hline & & & Yabancı & 319 & 1501 \\
\hline \multirow{2}{*}{2012} & \multirow{2}{*}{2} & \multirow{2}{*}{202} & Yerli & 25320 & 32225 \\
\hline & & & Yabancı & 402 & 1917 \\
\hline \multirow{2}{*}{2013} & \multirow{2}{*}{2} & \multirow{2}{*}{202} & Yerli & 24914 & 32211 \\
\hline & & & Yabancı & 216 & 1034 \\
\hline \multirow{2}{*}{2014} & \multirow{2}{*}{2} & \multirow{2}{*}{202} & Yerli & 22492 & 29399 \\
\hline & & & Yabanc1 & 257 & 1200 \\
\hline \multirow{2}{*}{2015} & \multirow{2}{*}{4} & \multirow{2}{*}{202} & Yerli & 17731 & 27423 \\
\hline & & & Yabancı & 1488 & 1807 \\
\hline \multirow{2}{*}{2016} & \multirow{2}{*}{4} & \multirow{2}{*}{202} & Yerli & 15971 & 25616 \\
\hline & & & Yabancı & 243 & 1268 \\
\hline \multirow{2}{*}{2017} & \multirow{2}{*}{7} & \multirow{2}{*}{519} & Yerli & 40716 & 68299 \\
\hline & & & Yabanc1 & 913 & 2769 \\
\hline \multirow{2}{*}{2018} & \multirow{2}{*}{7} & \multirow{2}{*}{541} & Yerli & 35745 & 62755 \\
\hline & & & Yabancı & 856 & 2074 \\
\hline \multirow{2}{*}{2019} & \multirow{2}{*}{7} & \multirow{2}{*}{541} & Yerli & 37068 & 62442 \\
\hline & & & Yabancı & 1220 & 3052 \\
\hline \multirow{2}{*}{2020} & 7 & & Yerli & 8863 & 14731 \\
\hline & 7 & 541 & Yabanc1 & 133 & 335 \\
\hline
\end{tabular}

Türkiye birçok medeniyeti barındırmış olan coğrafyasından dolayı kültürel açıdan son derece zengindir. Son yıllarda turizm aktiviteleri ve turist tercihleri dikkate alındığında bu kültürel zenginliğin ve dolayısıyla kültürel mirasların önemi de giderek artmaktadır. Yapılan birçok çalışma artık yerli ve yabancı turistin kültüre ve kültürel miraslara ilgisinin arttığını ortaya çıkarmaktadır (Altuntaş ve Tülek, 2012).

Son yıllarda kültürel miraslara artan bu ilgi ve Çankırı kenti kapsamında artan oranda yapılan kritik altyapı yatırımları ile birlikte Çankırı'nın yüksek turizm potansiyeli harekete geçmeye başlamıştır. Yakın gelecekte kültür ve tarih ziyareti kapsamında Çankırı'ya gelecek turist sayısının konaklamalı olanlar açısından yaklaşık \%10 artacağı, bunun yanında konaklamalı olmayanlar ise tahminen \%20 artacağı düşünülmektedir. Bu noktada özellikle kentte yer alan kültürel mirasların payı büyüktür. Çocuklar için okul turları, günü birlik ziyaretçiler, iş için günübirlik gelen tedarikçiler açısından ziyaretçi sayısının $18.000 \mathrm{kişi} / \mathrm{y} 1 \mathrm{l}$ olacağı öngörülmektedir (Çankırı Belediyesi, 2019b).

\subsection{1. Çankırı Kenti Somut Kültürel Mirasları}

$\mathrm{Bu}$ araștırma kapsamında Çankırı kent merkezi ve yakın çevresinde bulunan ve somut kültürel miraslar kapsamına giren Taş Mescit, Çankırı Kalesi ve Emir Karatekin Bey Türbesi, Sultan Süleyman Cami, Saat Kulesi, Buğday Pazarı Medresesi, Çivitçioğlu Medresesi, Çankırı Tarihi Çamaşırhanesi, İnandık Vazosu, Taş Mektep, İstiklal Yolu, Çankırı tuz mağarası ile somut olmayan kültürel miraslar kapsamına giren Yaran Kültürü 830 
ve Çankırı Takım Yemeği Çankırı'nın geleneksel kültürünün en tipik örnekleri olarak incelenmiştir (Şekil 2).

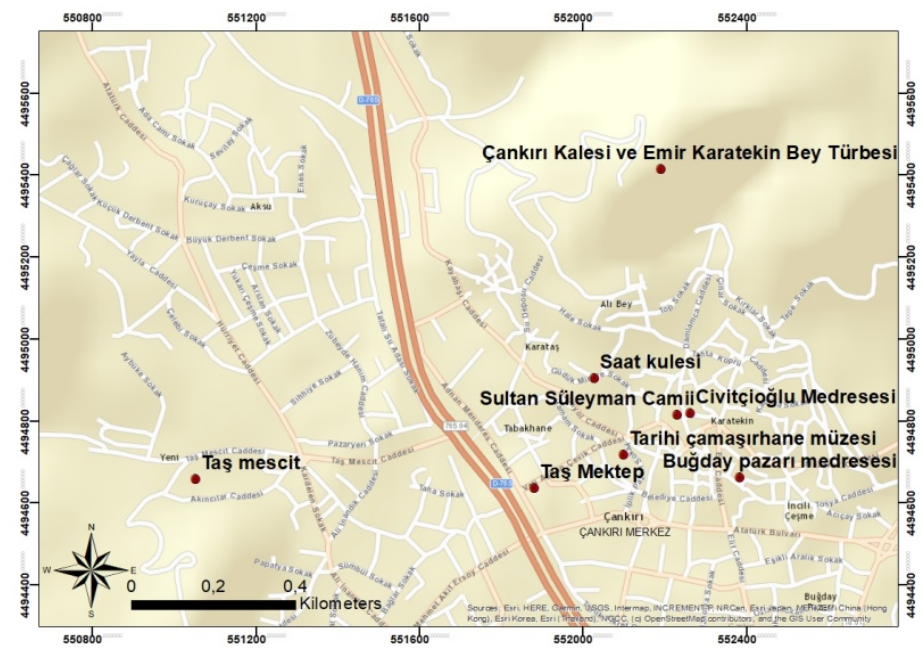

Şekil 2. Çankırı kenti somut kültürel miraslarının konumu

\section{Taş mescit}

Anadolu Selçuklu Hükümdarı I. Alâeddin Keykubat zamanında Çankırı Atabeyi (Valisi) Cemalettin Ferruh tarafından 1235 yılında yaptırılmıştır. Cemalettin Ferruh şifahaneye ilave olarak 1242 yılında bir Dâr-ûl Hâdis inşa ettirmiştir. Anadolu'daki ilk Dâr-ûl Hâdis olan eser halk tarafından Taş Mescit olarak isimlendirilmektedir. Mimari özelliğinin yanı sıra yapıya önem kazandıran diğer konu iki plastik sanat eseridir. Biri yap1 üzerinde, diğeri heykel görünümünde olan iki adet figürlü taş eserden birbirine dolanmış iki yılanın tasvir edildiği ve günümüzde "Tıp Sembolü” olarak kullanılan birinci parça yapı üzerinde bulunmaktadır. Çankırı Müzesinde sergilenen ikinci parçada ise günümüzde "Eczacılık Sembolü" olarak kullanılan kupaya dolanmış yılan figürü bulunmaktadır. Aynı zamanda bir anit mezar olan eserde iki adet mezar odası da yer almaktadır. Kuzey cephede yer alan mezar odasında bir sanduka yer almakta, doğu cephesinden girilen iki bölümlü mezar odasında ise beş sanduka bulunmaktadır. Kaditler olarak anılan cesetlerin döneminde mumyalandığı tahmin edilmektedir. $\mathrm{Bu}$ mezar odasinda ortada yer alan tabutun, eserin banisi Cemalettin Ferruh'a ait olduğu düşünülmekte sandukası mezar odasının üstünde ana mekanda yer almaktadır (Çankırı Valiliği, 2019a) (Şekil 3).

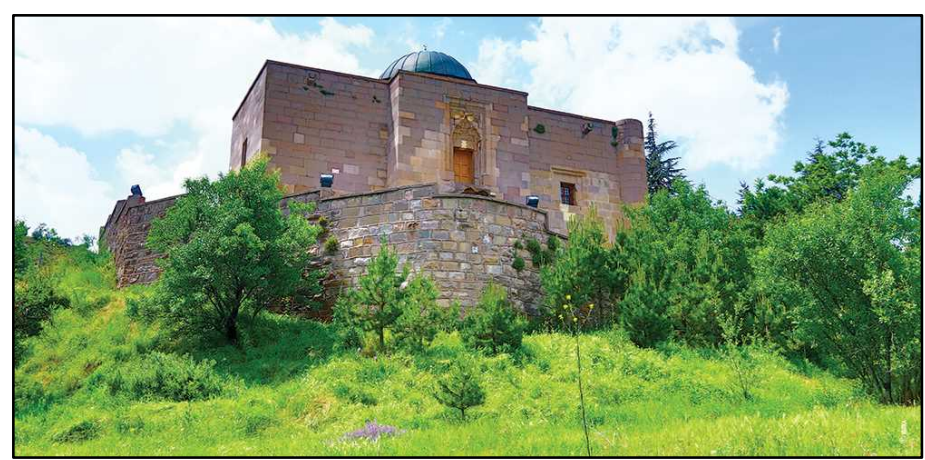

Şekil 3. Taşmescitten birgörünüş(Türkiye Kültür Portalı, 2021a)

\section{Çankırı Kalesi ve Emir Karatekin Bey Türbesi}

Romalılar, Bizanslılar, Danişmentliler, Selçuklular ve Osmanlılar dönemlerinde sağlamlığıyla ünlü yapıdan günümüze birkaç sur kalıntısı kalmıştır. Dörtgen planlı olan kalenin surları moloz taş ve tuğla karışımıdır. Yüksekliği 150 m. kadardır. Kale içinde Roma Dönemi'nden kalma kaya mezarı, iskan kalıntıları ve pişmiş toprak kap parçaları bulunmaktadır. Kalede Çankırı Fatihi Emir Karatekin Bey'in türbesi de bulunmaktadır. Kale bugün, ziyaretgâh ve mesire yeri olarak kullanılmaktadır (Türkiye Kültür Portalı, 2019) (Şekil 4).

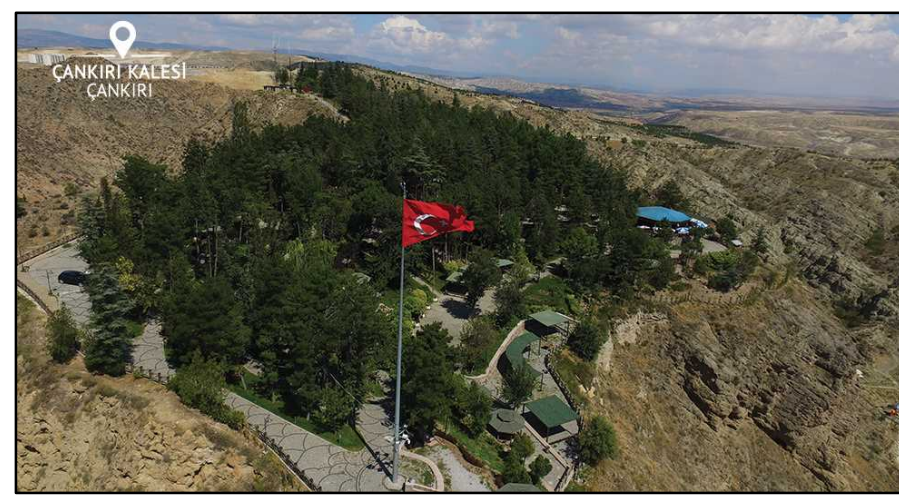

Şekil 4. Çankırı kalesi (Türkiye Kültür Portalı, 2021b)

\section{Sultan Süleyman Camii (Büyük camii / Ulu camii)}

Osmanlı Sultanı Kanuni Sultan Süleyman'ın emriyle Mimar Sinan'ın yetiştirdiği Sadık Kalfa tarafından yapılan cami, 1558 yılında ibadete açılmıştır. Merkez ilçede bulunan ve kare planlı olan Cami'nin üzerinde, ortada büyük tam kubbe ile bu kubbenin dört tarafında yarım kubbeler bulunmaktadır. Duvarları ve minaresi kesme taş, kubbe üstleri kurşun kaplıdır (Çankırı Valiliği, 2019b) (Şekil 5).

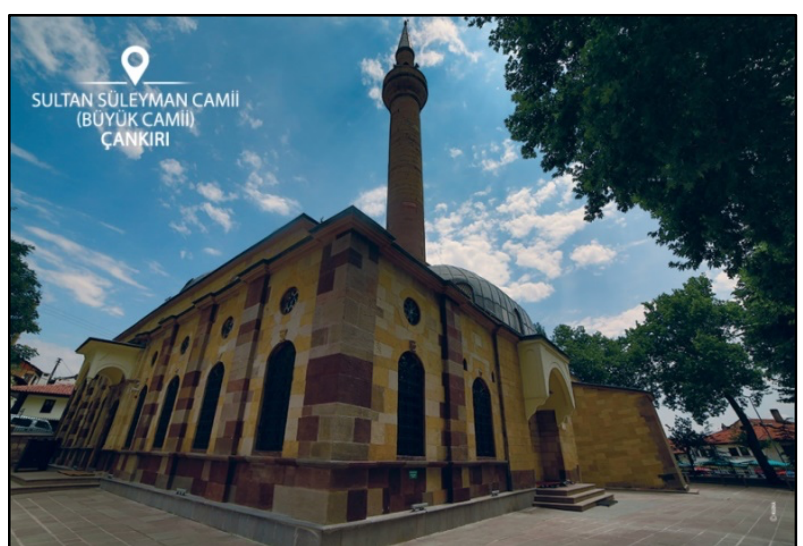

Şekil 5. Sultan Süleyman Camii (Türkiye Kültür Portall, 2021c)

\section{Çan saati (Saat kulesi)}

II. Abdülhamit Döneminden kalma yalın bir yapı olan saat kulesi için İsviçre'de üretilen saat 1866 yılında İnebolu yolu üzerinden Çankırı'ya getirilmiştir. Kare planlı ve dikdörtgen gövdeli olan saat kulesi bir platform üzerine oturtulmuştur. Şehre hakim bir noktada bulunan saat kulesinin yüksekliği 15 metredir. Üst kısmında balkon ve dört yönünde saat kadranları bulunmaktadır (Çankırı Valiliği, 2019c) (Şekil 6). 

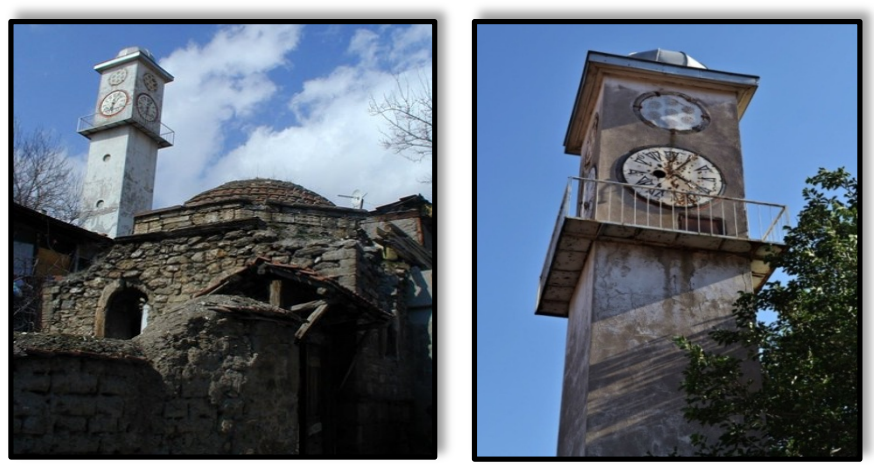

Şekil 6. Saat Kulesi (Çankırı İl Kültür ve Turizm Müdürlüğü,

2019c)

\section{Çivitçioğlu medresesi}

Çankırı'nın en önemli tarihi mekânlarından olan Çivitçioğlu Medresesi Çankırı Belediyesinin yaptığı tadilat ve tefriş düzenlemeleri sonunda kültür merkezi olarak hizmet vermektedir. Ebru kursları, hat ve rölyef kursları verilen medresenin özgün atmosferinde ney dinlemek de mümkündür (Çankırı Valiliği, 2019d) (Şekil 7).

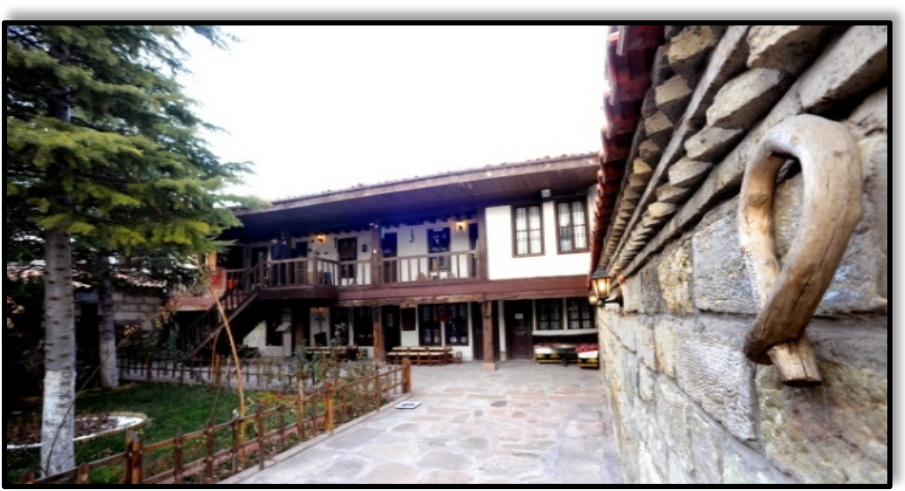

Şekil 7.Çivitçioğlu medresesinden görünüş (Çankırı Belediyesi,

2021b)

\section{Buğday pazarı medresesi}

Buğday Pazarı (Hazımiye) Medresesi hakkındaki kayitlarda Sofizade Mustafa Hazım Efendi tarafindan 18. yy'da inşa ettirildiği ve 19 yetişkin öğrencinin eğitim gördüğü bilgisi yer almaktadır. Buğday pazarı medresesi günümüzde kültürel amaçlı kullanılmaya başlanmıştır. Kaybolmaya yüz tutmuş el sanatlarının yanı sıra Çankırı'nın son yıllarda öne çıkan kaya tuzu hediyelik eşyalarının üretildiği ve tuz odasının oluşturulduğu Buğday Pazarı Medresesinde kentin geçmişini yansıtan somut olmayan kültürün yaşatıldığı odalar, yaran kültürünün tüm unsurları ve yöresel kıyafetler de sergilenmektedir. Medrese, Çankırı'ya gelenlerin en fazla ziyaret ettiği mekânlardan biridir (Çankırı Valiliği, 2019e) (Şekil 8).

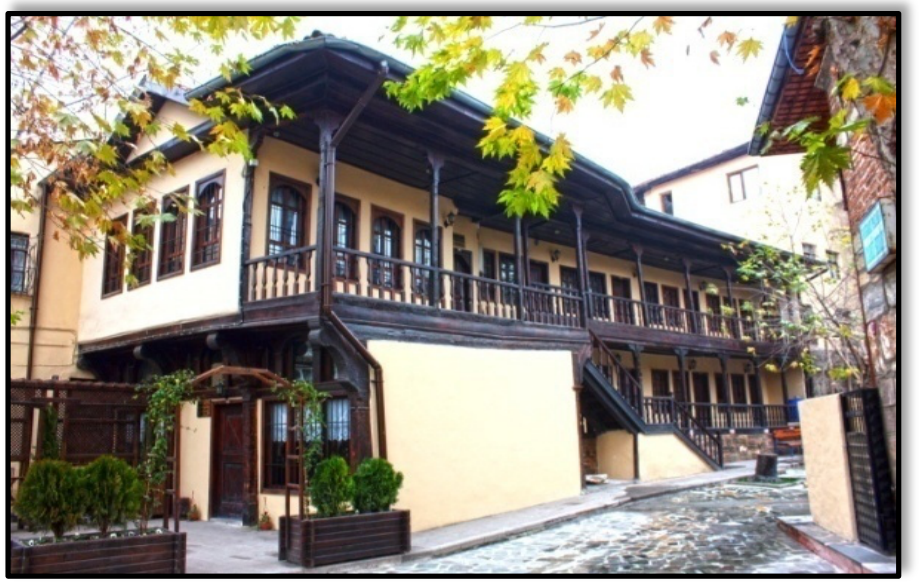

Şekil 8. Buğday pazarı medresesi (Anonim, 2015)

\section{Tarihi çamaşırhane müzesi}

Cumhuriyet Mahallesi'nde halkın ortak çamaşır yıkama yeri olması amacıyla yapılmış bir çamaşırhanedir. Çankırı Belediyesi tarafından restorasyonu yapılmış ve dönemin kültürünün yaşatıldığı bir müze haline getirilmiştir.. Aslına uygun şekilde düzenlenen çamaşırhanede; çamaşır yıkanan bölümler, çeşmeler, kazanlarda suların kaynatıldığı ocaklar, çamaşır dövülen taş sekiler, oluk, suların atıldığı açık kanallar, araç gereçler, heykeller, müze malzemelerinin sergilendiği vitrinler, hediyelik eşya satış birimi ve sunum panoları ile eski zaman çamaşırhane adetleri yaşatılmaktadır. Müze müzikle uğraşan gençlerin de uğrak yeridir. Çankırı Belediyesi Çivitçioğlu Medresesi Sanat Merkezi bünyesinde devam eden ney kursu öğrencileri ve def, bağlama ve saksafon çalan müzisyenler müzede bir araya gelmektedir (Çankırı Belediyesi, 2019b) (Şekil 9).

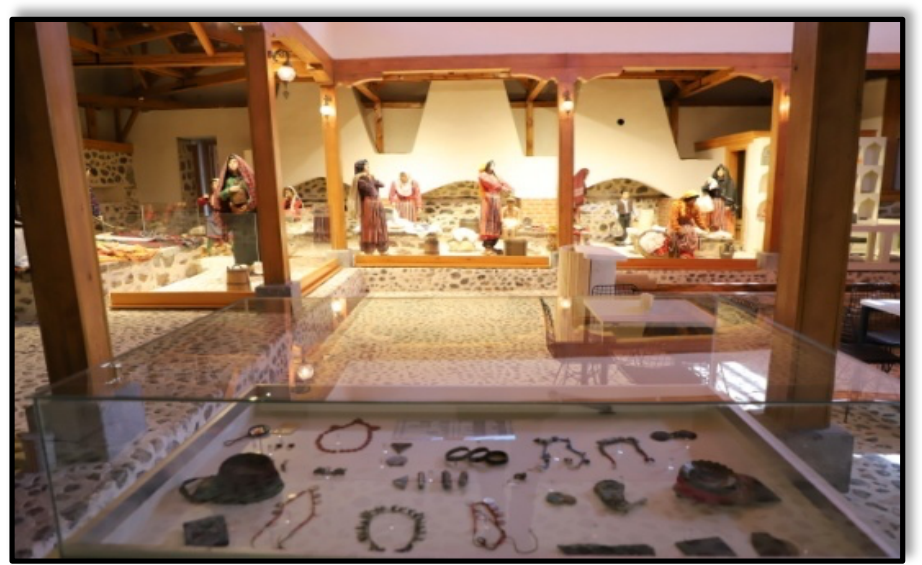

Şekil 9.Tarihi çamaşırhane müzesi (Çankırı Belediyesi, 2021c)

\section{Inandık vazosu}

İnandık Vazosu, Ankara ile Çankırı arasında İnandık Tepesi’nin üst kısmındaki Hitit tapınağında bulunmuştur. Eski Hitit döneminden (MÖ 1650-1450) kalma, pişmiş toprak bir vazodur (Anonim, 2019a) (Şekil 10). Kabartmalı motiflerin frizler halinde üzerine yerleştirildiği İnandık Vazosu, İnandık Höyüğ̈̈’ndeki yerleşmenin tarihini ve halkının yaşantısını aydınlatmasını sağlayan önemli bir buluntudur. 


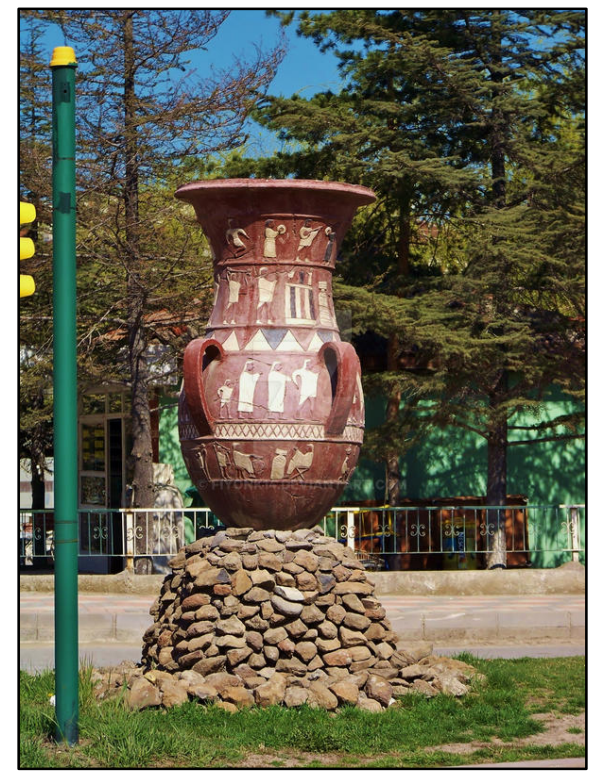

Şekil 10. Inandik vazosu (Anonim, 2009)

\section{Taş mektep}

Yapımına 1886 yılında başlanmış olan Taş mektep, 1893 yılında İdadi Mektebi adıyla açılmıştır. Merkez ilçede bulunan bina iki katlıdır ve kesme taştır. Bugün hala Güzel Sanatlar Lisesi olarak kullanılmaktadır. Yapının başka bir özelliği ise Atatürk'ün, 31 Ağustos 1925 gecesi Şapka İnkılabı nedeniyle çıktığı yurt gezisi sırasında bu binadaki bir dershanede ağırlanmasıdır. İmkânlar doğrultusunda tefriş edilen dersane, günümüzde "Atatürk Odası" olarak dönüştürülmüştür (Çankırı Valiliği, 2019f) (Şekil 11).

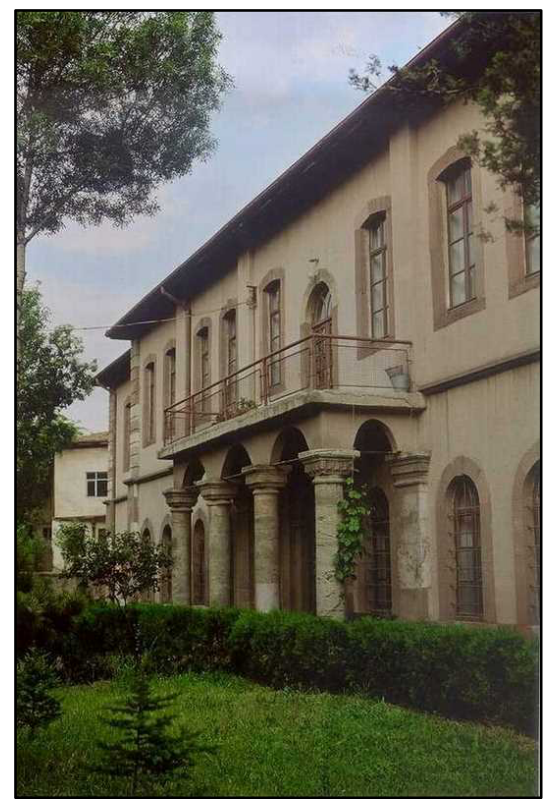

Şekil 11. Taş mektep (Türkiye Kültür Portal,, 2021d)

\section{Istiklal yolu}

İstiklal yolu $344 \mathrm{~km}$ uzunluğunda, coğrafi açıdan zorlu bir güzergâhtır. İnebolu, Kastamonu, Ilgaz, Çankırı, Kalecik, Ankara hattı olan bu güzergah; İstiklal Savaşı'nda cephe gerisinin önemli bir lojistik yoludur (Şekil 12). Bu yoldan çok sayıda silah ve cephane taşınmıştır. Savaşın kaderinin belirlenmesinde etkili olan bu güzergah için Başkumandan
Mustafa Kemal, “Gözüm Sakarya'da, Dumlupınar'da; Kulağım İnebolu'da" şeklinde bahsetmiştir (İstiklal Yolu Derneği, 2019a).

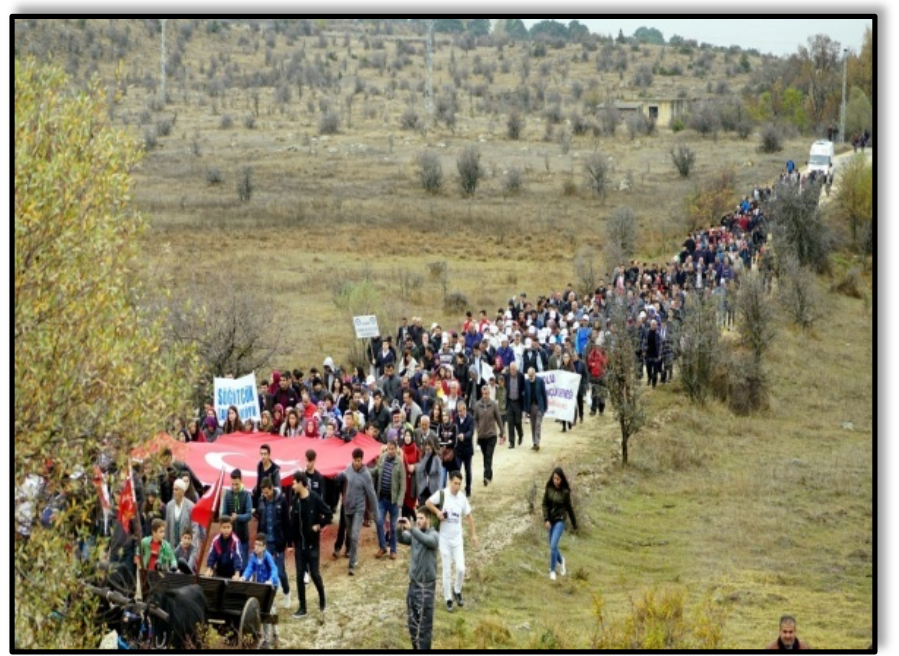

Şekil 12. İstiklal yolu yürüyüşü (İstiklal Yolu Derneği, 2019b)

\section{Tuz mağarast}

Merkez ilçeye $19 \mathrm{~km}$. mesafede bulunan ve Hititler Döneminden beri işletildiği tahmin edilen tuz yatakları Türkiye'nin en büyük kaya tuzu rezervine sahiptir (Anonim, 2019b). Tuz elde etmek için açılan oyuklardan oluşan ve içerisinde kamyonların dolaştığı mağara oldukça görkemlidir. Bazı bölümlerinde tuz sarkıt ve dikitlerinin bulunduğu mağarada üretilen kaya tuzu Çankırı'da bulunan tuz fabrikalarında işlenmekte ve ülke genelinde sofra ve sanayi tuzu olarak pazarlanmaktadır. Bugün hala özel sektör tarafından mağaradan tuz üretimi yapılmaktadır. Üretim faaliyeti tamamlanmış galerilerin turizme kazandırılması amacıyla galerilerin bir bölümü Çankırı Valiliğine devredilmiştir ve "Çankırı Kaya Tuzu Mağarasının Turizme Kazandırılması Projesi" hazırlanmıştır. Proje kapsamında mağarada heykel ve rölyeflerin yer alacağı galeriler, yaran kültürü tanıtım galerisi, restoran, kafeterya, çok fonksiyonlu toplantı salonu, çocuk oyun alanı, fosil müzesi, mescit, mağara içi 1şık sistemleri, dekoratif tuz havuzu, spor aktivite alanı ile astım, bronşit gibi akciğer rahatsızlıklarının tedavisine yönelik tuz terapi odalarının hazırlanması planlanmıştır. Böylece mağara sağlık turizmi açısından da önem taşıyacak bir alan haline gelecektir (Çankırı Valiliği, 2019g) (Şekil 13).

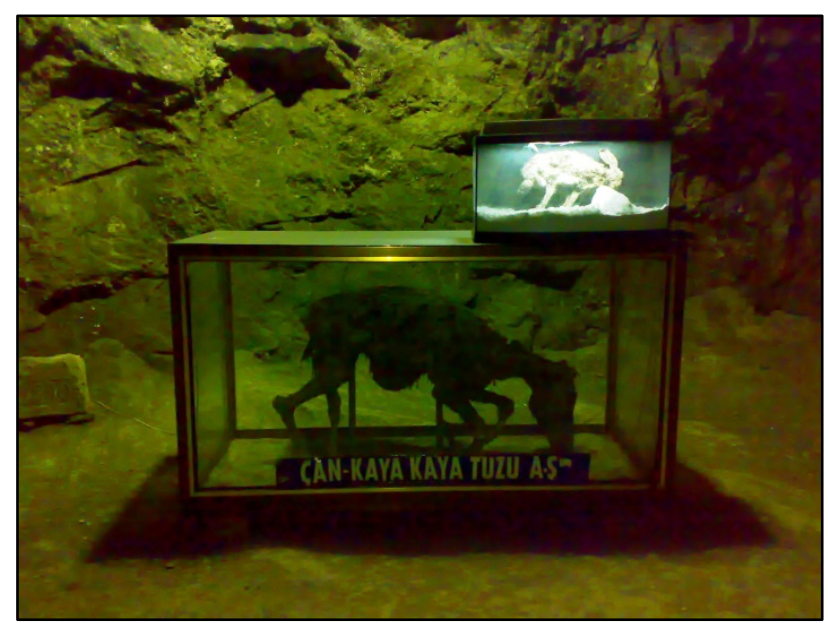

Şekil 13. Çankırı Tuz mă̆arasından bir görüntü (Orijinal,2013) 


\subsection{2. Çankırı Kenti Somut Olmayan Kültürel Mirasları}

Araştırma alanı içerisinde geçmişten günümüze yapılan somut olmayan kültürel miras çalışmaları Tablo 4'te verilmiştir.

Tablo 4. Araştırma Alanı Somut Olmayan Kültürel Miras Çalışmaları (Çankırı Il Kültür ve Turizm Müdürlügüu, 2019a)

2008 SÖKÜM komisyonu kurulmuştur. 27-28 Şubat 2009 tarihlerinde Çankırı ilinde"Yaran Kültürünü Koruma Eylem Planı Çalıştayı" gerçekleştirilmiştir. Eldivan'da yaşatılmakta olan Seymen geleneği ile ilçelerin çoğunluğunda yaşatılan Keşkek geleneğinin de Çankırı ili Somut Olmayan Kültürel Miras listesinde yer alması teklifi yapılmıştır.

Yaran geleneği 2010 yılında UNESCO tarafindan Somut

2010 Olmayan Kültürel Mirasın Temsili Listesine alınmıştır. UNESCO tarafindan Somut Olmayan Kültürel Mirasın

2011 Temsili Listesine alınan Yaran Kültürünü Çankırı ilinde yaşatan grup ve kişilerle ilgili bilgilerin güncellenmesi yapilmıştır.

Çankırı ilindeki El kuklası oynatma geleneğinin tek temsilcisi olan Mehmet GÜMÜŞ adına bakanlığa "Somut Olmayan Kültürel Miras Taşıyıcıları Tespit ve Kayıt İşlemleri Yönergesi” kapsamında müracaatta

2014 bulunulmuş ve sanatçı kaydı yaptırılmıştır.2009 yılında yapılan teklif üzerine 2014 yılında toplanan Komisyonca Yaran, Kazanda Keşkek ve Seymen Geleneği Somut Olmayan Kültürel Miras İl ve Ulusal Envanterine kayıt edilmesine karar verilmiştir.

Bu gelişmeler ışığına Çankırı kenti somut olmayan kültürel mirasları Yaran Kültürü ve Takım yemeği kapsamında incelenmiştir.

\section{Yaran kültü̈rü}

Yaran; Türk örf, adet ve gelenekleri ile İslam, ahlak ve faziletinin bütünleşmesi sonucu meydana gelen ve ahiliğin temel prensipleri olan kaliteli üretim, hilesiz satış felsefesi bağlamında esnaf yetiştiren ve Oğuzlardan günümüze kadar yaşatılan milli kültür mirasıdır. Kış döneminde yakılan ocaklarla varlığını sürdüren Yaran geleneği gönüllülük esasına dayanmaktadır. Kendine özgü olarak örgütlenmiş, üyelerinin kendi dilekleri ile katıldığı sürekli bir topluluktur. Yüz yüze, kendi ihtiyaçlarını giderici, geleneğin yaşatılması için çabalayan yaran elemanları ilgi birliği, toplumsallaşma ve inançların pekiştirilmesi özelliklerinin gelişmesine katkıda bulunmaktadır (Çankırı Valiliği, 2019h) (Şekil 14).

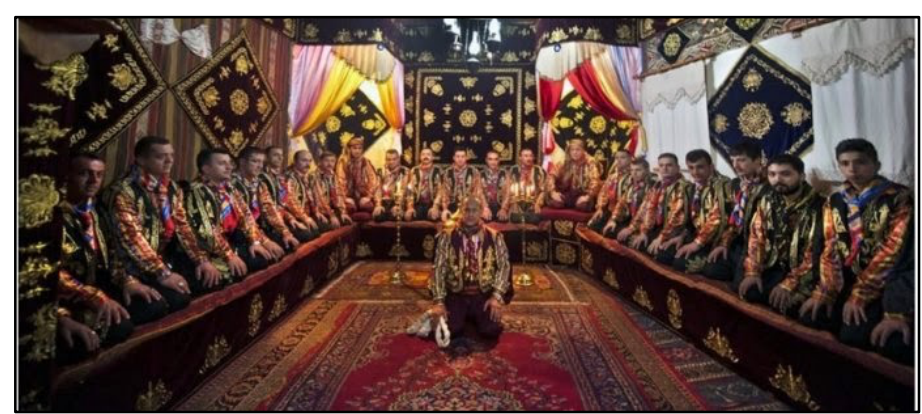

Şekil 14. Yaran Meclisi (Anonim, 2014)

\section{Takım Yeme ği}

Çankırı ve yöresinde iftar davetleri dışında evlenecek olan genç kız ve arkadaşları yakın akrabaları tarafından akşam yemeklerine davet edilmektedir. Ayrıca yeni evlenen gençler de yakın akrabaları tarafından sıra ile akşam yemeklerine davet edilmektedirler. Askere gidecek delikanlılar da yakın akrabaları tarafindan akşam yemeklerine davet edilirler. Bazı köy ve kasabalarda askere gidecek o dönem delikanlılarının hepsi yakın akrabaları tarafindan hep birlikte davet edilir. $\mathrm{Bu}$ davetlerde menüsüne göre 6 farklı özel menü hazırlanmaktadır (Çankırı İl Kültür ve Turizm Müdürlüğü, 2019b).

\section{Sonuç}

Çevreyi oluşturan doğal ve kültürel kaynaklar ile turizmin ilişkisi, bu kaynakların korunması ve değer kazanmaları açısından araç ve amaç birlikteliği oluşturmaktadır. Bu kaynak değerleri yerinde geliştirildiği zaman değer kazanmaktadır.

Bir bölgenin kültür turizmini önemli kılan kültürel değerleri resim, müzik, dans, endüstri, el sanatları, iş, tarım, eğitim, edebiyat, dil, bilim, yönetim, din, mutfak ve tarih özelliklerinin yanı sıra, bölgenin mimari dokusu ve eserleri ile bölge halkı oluşturmaktadır (Çetin, 2010).

Ziyaretçiler gittikleri bölgelerin kültürlerini, geleneklerini, folklörlerini, doğal özelliklerini ve tarihini deneyimlemek; bunların yanında doğa ve macera sporları yapıp, festivaller, el sanatları gibi etkinliklere katılarak da kültür turizmi aktivitelerini gerçekleştirmek isterler (MacDonald ve Joliffe, 2003). Bu noktada unutulmaması gereken, ziyaret edilen yöre veya bölgenin kültür turizmi olarak gelişebilmesi için, ziyaretçilere sunulan tüm ürün ve hizmetlerin o yöreye ait, özgün olması ve kültürel bir yönetim ve yaşam tarzını sergilemesidir (Bachlaitner ve Zins, 1999).

Çankırı ili için kültür turizmi açısından kentte bulunan kültürel mirasların önemi büyüktür. Araştırmada ele alınan ve somut kültürel miras kapsamına giren unsurların, kültürel ve tarihi yapıların korunması ve gelecek nesillere aktarılabilmesi amacı ile kamu kurumları tarafindan korunmaya alınması yönünde önemli çalışmalar yürütülmüştür. Özellikle Çankırı Belediyesi ve Vakıflar Genel Müdürlüğü restorasyon çalışmaları yürüterek, bu unsurların turizm alt yapısını güçlendirmişlerdir. Somut olmayan kültürel mirasların nesilden nesile aktarılabilmesi için de yaran dernekleri düzenli çalışmalar yürütmektedir. Yaran Kültürü'nün sürdürülebilirliğinin sağlanması için hala belirli zamanlarda yaran geceleri düzenlenerek bu kültür yaşatılmakta ve takım yemeği ikramı geleneği devam ettirilmektedir.

Çankırı kent merkezi ve yakın çevresinde bulunan kültürel mirasların Çankırı turizmine ivme kazandırdığı özellikle son yıllardaki turizm verilerinden anlaşılmaktadır. Ancak turizm açısından talebin arttırılması için bu kültürel ve tarihi değerlerin ulusal ve uluslararası platformlarda tanıtım çalışmaları yürüterek kültür turizmine ilgisi olan kişilerde farkındalık oluşturulması gerekmektedir. Ayrıca Çankırı ili, Kuzey Anadolu Kalkınma Ajansı'nın bölge turizmi ile ilgili yapmış olduğu araştırmalarda herhangi bir turizm rotasında bulunmadığı sonucu ortaya çıkarılmıştır. Çankırı'da turizmin canlandırılması ve turizm gelirlerinin artması için sahip olduğu kültürel mirasların tanıtımının yapılarak hem şehir içi rota planlaması hem de şehirlerarası turizm rotası oluşturulması yolunda çalışmalar 
yürütülmesi gerekmektedir. Çankırı Belediyesi’nden alınan bilgiler doğrultusunda Çankırı kent merkezine gelen turistler için konaklama tesislerinin sayısı 2020 yılı itibariyle 7'dir. Çankırı ili için 2019 yılında kente gelen yerli ve yabancı turist sayısı 38.288; geceleme sayıs 65.494 olarak tespit edilirken; bu say1 2020 yılı için 8.996, geceleme sayısı ise 15.066 olarak belirlenmiştir. Kentteki konaklama tesislerinin sayısı ve yatak kapasitesi arttırılmalıdır. Ayrıca görüldüğü üzere yabancı turistin payı çok düşüktür. Bu kapsamda 2020 yılındaki turist sayısının azalmasında COVID 19 salgının etkisi de oldukça fazladır (Çankırı Belediyesi, 2021) (Tülek ve Atik, 2020).

Çankırı kenti somut olmayan kültürel miraslarından olan takım yemeği kültürü ise Çankırı halkı tarafından evlerinde sürdürülmektedir. Şehir merkezinde sadece bir lokanta bu konuda hizmet vermektedir. Çankırı somut olmayan kültürel miras listesinde olan geleneksel lezzetlerin yer aldığı takım yemeğinin yerli ve yabancı turistlere ulaşması ve daha fazla işletmede hizmet verilmesi açısından girişimciler teşvik edilmelidir. Yapılacak tüm bu çalışmalarla Çankırı'ya ait somut ve somut olmayan kültürel mirasların tanıtılması, korunması ve turizme kazandırılmaları konularında katkı sağlanmış olacaktır.

\section{Kaynakça}

Akgül, O., (2003). Turistik Ürün Çeşitlendirmesi Kapsamında Kültür Turizmi, Aphrodisias-Geyre Örneği, Adnan Menderes Üniversitesi, Sosyal Bilimler Enstitüsü, Turizm Anabilim Dalı yayınlanmamış Yüksek Lisans Tezi, Aydın.

Altuntaş, A.,Tülek, B., (2012). Kültürel Peyzajların Turizme Etkileri: Antalya Örneği, II. Disiplinlerarası Turizm Araştırmaları Kongresi: 444-458, 12 - 15 Nisan 2012, Antalya

Anonim, (2009). İnandik Vazosu. Web Sitesi: https://www.deviantart.com/fiyonk14/art/inandik-vazosu118897040, Erişim Tarihi: 25.02.2021.

Anonim, (2011). Soyut Kültürel Miras, Web Sitesi: http://www.turkiyekulturportali.gov.tr/Sayfalar/KulturelMira s/Soyut $\% 20 \mathrm{~K} \% \mathrm{C} 3 \%$ BClt $\% \mathrm{C} 3 \% \mathrm{BCrel} \% 20 \mathrm{Miras} /$ Somut $\% 2$ 0Olmayan $\% 20 \mathrm{~K} \% \mathrm{C} 3 \% \mathrm{BClt} \% \mathrm{C} 3 \% \mathrm{BCrel} \% 20$ Miras.aspx? is $\mathrm{p}=$ 1.Erişim Tarihi: 01.04.2019

Anonim, (2014). Yaranlar Diyarı - Kaya Tuzunun Başkenti ÇANKIRI, Web Sitesi: http://yaranlardiyari.blogspot.com/2014/04/cankiri-vecevresine-ozgu-yaran-kulturu.html, Erişim Tarihi: 25.02 .2021 .

Anonim, (2015). Çankırı'nın iki medresesi. Web Sitesi: https://www.dunyabulteni.net/dunyanin-bir-ucu/cankirininiki-medresesi-h322282.html, Erişim Tarihi: 25.02.2021.

Anonim, (2019a). İnand1k Vazosu. Web Sitesi: https://derstarih.com/inandik-vazosu/. Erişim Tarihi: 01.04 .2019

Anonim, (2019b). Tuz Mağaras1. Web Sitesi: https://www.tuzlamba.com/blog/tuz-magarasi. Erişim Tarihi: 09.04.2019

Arınç, P. C., (2002). Selçuk'ta Kültür Turizmi, İzmir: Ege Üniversitesi Sosyal Bilimler

Bachlaitner, R., Zins, A. H., (1999). "Cultural Tourism in Rural Communities: The Residents' Perspective", Journal of Business Research, 44: 199-209.

Bahçe, A. S., (2009). Kırsal Gelişimde Kültür (Mirası) Turizmi Modeli. Dumlupınar Üniversitesi Sosyal Bilimler Dergisi, $25,1-13$
Bıçk1, D., Ak, D., Özgökçeler S., (2013). Avrupa'da ve Türkiye'de Sosyal Turizm. Muğla Sitk1 Koçman Üniversitesi Sosyal Bilimler Enstitüsü Dergisi, 31, 49-73

Can, M., (2009). Kültürel Miras ve Müzecilik. Turizm ve Kültür Bakanlığı, Çalışma Raporu, Enstitüsü Coğrafya Anabilim Dalı ( Yayınlamamış Yüksek Lisans Tezi)

Çankırı Belediyesi, (2019a). Kent Rehberi / Kültür. Web Sitesi: http://www.cankiri.bel.tr/sayfa-13/kultur.php. Erişim Tarihi: 01.04.2019.

Çankırı Belediyesi, (2019b). Tarihi Çamaşırhane. Web Sitesi: http://www.cankiri.bel.tr/sayfa-89/tarihi-camasirhanemuzesi.php. Erişim Tarihi: 01.04.2019

Çankırı Belediyesi, (2021a). TR82 Bölgesi Çankırı İlinin Turizm Potansiyeli Çalışması.

Çankırı Belediyesi, (2021b). Çivitçioğlu Medresesi Web Sitesi: https:/www.cankiri.bel.tr/civitcioglu-medresesi,7,1065,1, Erişim Tarihi: 25.02.2021.

Çankırı Belediyesi, (2021c). Tarihi Çamaşırhane Müzesi, Web Sitesi: https://www.cankiri.bel.tr/tarihi-camasirhanemuzesi,7,89,1, Erişim Tarihi: 25.02.2021.

Çankırı İl Kültür ve Turizm Müdürlüğü, (2019a). Araştırma Alanı Somut Olmayan Kültürel Miras Çalışmaları

Çankırı İl Kültür ve Turizm Müdürlüğü, (2019b). Takım Yemeği

Çankırı İl Kültür ve Turizm Müdürlüğü, (2019c). Saat Kulesi ve Taş Mektep Fotoğrafları

Çankırı Ticaret ve Sanayi Odası, (2019).Çankırı Özellikleri. Web Sitesi:

http://www.catso.org.tr/\%C3\%87ank $\% \mathrm{C} 4 \% \mathrm{~B} 1 \mathrm{r} \% \mathrm{C} 4 \% \mathrm{~B} 1 / \%$ C3\%87ank\%C4\%B1r\%C4\%B1Tarih\%C3\%A7e/tabid/1512 0/Default.aspx. Erişim Tarihi: 01.04.2019

Çankırı Valiliği, (2019a). Taşmescit. Web Sitesi: http://www.cankiri.gov.tr/tas-mescit-cemaleddin-ferruhdrulhadsi. Erişim Tarihi: 01.04.2019

Çankırı Valiliği, (2019b). Sultan Süleyman Camii (Büyük camii/ Ulu camii). Web Sitesi: http://www.cankiri.gov.tr/ulu-camisultan-suleyman-cami. Erişim Tarihi: 01.04.2019

Çankırı Valiliği, (2019c). Çan Saati (Saat Kulesi). Web Sitesi: http://www.cankiri.gov.tr/can-saati-saat-kulesi. $\quad$ Erişim Tarihi: 01.04.2019

Çankırı Valiliği, (2019d). Çivitçioğlu Medresesi. Web Sitesi: http://www.cankiri.gov.tr/civitcioglu-medresesi. $\quad$ Erişim Tarihi: 01.04.2019

Çankırı Valiliği, (2019e). Buğday Pazarı Medresesi. Web Sitesi: http://www.cankiri.gov.tr/bugday-pazari-medresesi. Erişim Tarihi: 01.04.2019

Çankırı Valiliği, (2019f). Taş Mektep. Web Sitesi: http://www.cankiri.gov.tr/tas-mektep. Erişim Tarihi: 01.04.2019

Çankırı Valiliği, (2019g). Tuz Mağarası. Web Sitesi: http://www.cankiri.gov.tr/tuz-magarasi. Erişim Tarihi: 02.04.2019

Çankırı Valiliği, (2019h). Yaran Kültürü. Web Sitesi: http://www.cankiri.gov.tr/yaran Erişim Tarihi: 02.04.2019

Çetin, T., (2010). Cumalıkızık Köyü’nde Kültürel Miras ve Turizm Algısı, Milli Folklor Üç Aylık Uluslararası Kültür Araştırmaları Dergisi, 22(87): 181-190.

İstiklal Yolu Derneği, (2019a). İstiklal Yolu. Web http://www.istiklalyolu.com//iyoluhakkinda/GenelBilgiler.html. Erişim Tarihi: 01.04.2019

İstiklal Yolu Derneği, (2019b). İstiklal Yolu. Web http://www.istiklalyolu.com//FotografKategori/CepheGerisi.html Erişim Tarihi: 01.04.2019 
Kuzka, (2013). Kuzey Anadolu Kalkınma Ajansı, Çankırı. Web Sitesi:

https://www.kuzka.gov.tr/bolgemiz.asp?B=17\&Bolgemiz $=\mathrm{c}$ ankiri. Erişim Tarihi: 17.04.2019.

Macdonald, R., Joliffe, L., (2003). "Cultural Rural Tourism Evidence from Canada", Annals of Tourism Research, 302:308.

Meydan Uygur, S., Baykan, E., (2006). Kültür Turizmi Ve Turizmin Kültürel Varlıklar Üzerindeki Etkileri. Ticaret ve Turizm Eğitim Fakültesi Dergisi, 2, 30-49.

Sezer, İ., (2017). Kültürel Mirasın Turizm Açısından Değerlendirilmesi: Taşköprü İlçesi Örneği. Uluslararası Türk Dünyası Turizm Araştırmaları Dergisi, 2(2), 175-198.

T.C. Kültür ve Turizm Bakanlığı, (2019). Somut Olmayan Kültürel Miras. Web Sitesi: http://aregem.kulturturizm.gov.tr/TR-46095/somut-olmayankulturel-miras.html. Erişim Tarihi: 21.03.2019

TDK, (2019). Türk Dil Kurumu, Turizm Kavramı. Web Sitesi: http://www.tdk.gov.tr/index.php?option=com gts\&arama=gt s\&guid=TDK.GTS.5cb055ff426832.58072918. $\quad$ Erişim Tarihi: 24.03.2019.

Teo, P., Yeoh, B. S. A., (1997). "Remaking Local Heritage For Tourism", Annals of Tourism Research, 24-1:192-21.

TÜIK, 2021. Nüfus Kayit Sistemi, https://biruni.tuik.gov.tr/medas/?kn=95\&locale=tr, Erişim Tarihi: 23.02.2021.

Tülek, B., Atik, M., (2021). Çankırı Kalesi'nin Tarihi Kentsel Peyzaj Yaklaşımı (HUL) ile Değerlendirilmesi . Artium , 9 (1) , 21-27 . DOI: 10.51664/artium.796315.

Türkiye Kültür Portalı, (2019). Çankırı Kalesi ve Emir Karatekin Bey Türbesi. Web Sitesi: https://www.kulturportali.gov.tr/turkiye/cankiri/gezilecekyer /cankiri-kalesi-ve-karatekin-bey-turbesi. Erişim Tarihi: 01.04 .2019

Türkiye Kültür Portalı, (2021a). Taş Mescit - Çankırı. Web Sitesi:

https://www.kulturportali.gov.tr/turkiye/cankiri/gezilecekyer tas-mescit-cemalddin-ferruh-dar-ul-hadis Erişim Tarihi: 25.02.2021

Türkiye Kültür Portalı, (2021b). Çankırı Kalesi, Web Sitesi: https://www.kulturportali.gov.tr/turkiye/cankiri/gezilecekyer /cankiri-kalesi-ve-karatekin-bey-turbesi Erişim Tarihi: 25.02.2021

Türkiye Kültür Portalı, (2021c). Sultan Süleyman Cami Çankırı, Web Sitesi: https://www.kulturportali.gov.tr/turkiye/cankiri/gezilecekyer /sultan-suleyman-cami-buyuk-cami, Erişim Tarihi: 25.02.2021.

Türkiye Kültür Portalı, (2021d). Taş Mektep - Çankırı. Web Sitesi:

https://www.kulturportali.gov.tr/turkiye/cankiri/gezilecekyer /tas-mektep, Erişim Tarihi: 25.02.2021.

UNESCO, (2021a). Dünya Miras Listesi. Web Sitesi: http://www.unesco.org.tr/Pages/125/122/UNESCOD\%C3\%BCnya-Miras\%C4\%B1-Listesi Erişim Tarihi: 20.02.2021

UNESCO, (2021b). UNESCO İnsanlığın Somut Olmayan Kültürel Mirası Temsili $\quad$ Listesi http://www.unesco.org.tr/Pages/126/123/UNESCO $\%$ C4\%B 0nsanl\%C4\%B1\%C4\%9F\%C4\%B1n-Somut-OlmayanK\%C3\%BClt\%C3\%BCrel-Miras\%C4\%B1-TemsiliListesi,Erişim Tarihi: 20.02.2021
UNWTO, (2019). Türkiye Turizm Stratejisi 2023 Eylem Planı, Web Sitesi: http://www.kultur.gov.tr/Eklenti/906,ttstratejisi2023pdf.pdf? 0. Erişim Tarihi: 24.03.2019

Yıldırım Saçılık, M., Toptaş A., (2017). Kültür Turizmi ve Etkileri Konusunda Turizm Öğrencilerinin Algılarının Belirlenmesi. Turizm Akademik Dergisi, 4(2), 107-119. 